\title{
Nucleosomes Indicate the in vitro Radiosensitivity of Irradiated Bronchoepithelial and Lung Cancer Cells
}

\author{
Stefan Holdenrieder ${ }^{a}$ Jutta Stief ${ }^{b}$ Albrecht Bergner ${ }^{b}$ Fernando Gamarra ${ }^{b}$ \\ Anke Mitlewski a Dorothea Nagela Rudolph M. Huber ${ }^{b}$ Petra Stieber ${ }^{a}$ \\ a Institute of Clinical Chemistry, and b Department of Pulmology, Ludwig-Maximilians-University of Munich, \\ Munich, Germany
}

\section{Key Words}

Apoptosis · Cell cultures · Cell death · Irradiation · Lung cancer $\cdot$ Nucleosomes $\cdot$ Radiosensitivity

\begin{abstract}
Nucleosomes, which are typical cell death products, are elevated in the serum of cancer patients and are known to rapidly increase during radiotherapy. As both normal and malignant cells are damaged by irradiation, we investigated to which extent both cell types contribute to the release of nucleosomes. We cultured monolayers of normal bronchoepithelial lung cells (BEAS-2B, $n=18$ ) and epithelial lung cancer cells (EPLC, $n=18$ ), exposed them to various radiation doses $(0,10$ and $30 \mathrm{~Gy})$ and observed them for 5 days. Culture medium was changed every $24 \mathrm{~h}$. Subsequently, nucleosomes were determined in the supernatant by the Cell Death DetectionELISA ${ }^{\text {plus }}$ (Roche Diagnostics). Additionally, the cell number was estimated after harvesting the cells in a second preparation. After 5 days, the cell number of BEAS-2B cultures in the irradiated groups ( $10 \mathrm{~Gy}$ : median $0.03 \times$ $10^{6}$ cells/culture, range $0.02-0.08 \times 10^{6}$ cells/culture; $30 \mathrm{~Gy}$ : median $0.08 \times 10^{6}$ cells/culture, range $0.02-0.14$ $\times 10^{6}$ cells/culture) decreased significantly (10 Gy: $p=$
\end{abstract}

\section{KARGER}

Fax +4161306 1234

E-Mail karger@karger.ch

www.karger.com
(C) 2004 S. Karger AG, Basel

$1010-4283 / 04 / 0256-0321 \$ 21.00 / 0$

Accessible online at:

www. karger.com/tbi
0.005; 30 Gy $p=0.005$; Wilcoxon test) compared to the non-irradiated control group (median $4.81 \times 10^{6}$ cells/ culture, range $1.50-9.54 \times 10^{6}$ cells/culture). Consistently, nucleosomes remained low in the supernatant of nonirradiated BEAS-2B. However, at $10 \mathrm{~Gy}, \mathrm{BEAS-2B}$ showed a considerably increasing release of nucleosomes, with a maximum at $72 \mathrm{~h}$ (before irradiation: 0.24 $\times 10^{3}$ arbitrary units, $A U$, range $0.13-4.09 \times 10^{3} \mathrm{AU}$, and

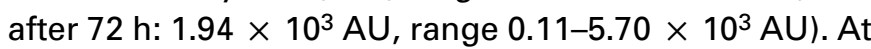
$30 \mathrm{~Gy}$, the release was even stronger, reaching the maximum earlier (at $48 \mathrm{~h}, 11.09 \times 10^{3} \mathrm{AU}$, range 6.89-18.28 $\left.\times 10^{3} \mathrm{AU}\right)$. In non-irradiated EPLC, nucleosomes constantly increased slightly. At $10 \mathrm{~Gy}$, we observed a considerably higher release of nucleosomes in EPLC, with a maximum at $72 \mathrm{~h}$ (before irradiation: $2.79 \times 10^{3} \mathrm{AU}$, range $2.42-3.80 \times 10^{3} \mathrm{AU}$, and after $72 \mathrm{~h}: 7.16 \times 10^{3} \mathrm{AU}$, range $4.30-16.20 \times 10^{3} \mathrm{AU}$ ), which was more than 3.5 times higher than in BEAS-2B. At $30 \mathrm{~Gy}$, the maximum $\left(6.22 \times 10^{3} \mathrm{AU}\right.$, range 5.13-9.71 $\left.\times 10^{3} \mathrm{AU}\right)$ was observed already after $24 \mathrm{~h}$. These results indicate that normal bronchoepithelial and malignant lung cancer cells contribute to the release of nucleosomes during irradiation in a dose- and time-dependent manner with cancer cells having a stronger impact at low doses.

Copyright $\odot 2004$ S. Karger AG, Base

Dr. med. Petra Stieber

Klinikum der Universität München-Grosshadern

Marchioninistrasse 15, DE-81377 München (Germany)

Tel. +49 897095 3115, Fax +498970956298

E-Mail Petra.Stieber@med.uni-muenchen.de 


\section{Introduction}

Ionizing radiation is established as an essential part of the therapy of many malignant diseases. Similar to chemotherapy, it affects mainly fast proliferating cells and tissues with high turnover, such as tumor cells but also stem cells, lymphocytes and epithelial cells [1]. Therefore radiotherapy protocols aim both to reduce tumor size and to limit potential side effects.

It is well known that radiation induces cell death already at low doses. Although still controversial, apoptosis seems to play an important role in many cell types $[2,3]$. However, oncosis and other forms of cell death may contribute to cell loss particularly at high doses [4].

The effects of radiotherapy - single- and double-strand DNA breaks - are mediated directly, by activation of the CD95/Apo1/Fas receptor system and a proteolytic cascade of caspases, or by stimulation of the mitochondria, or by direct damage of the DNA. Often, p53 is upregulated leading to an arrest of the cell cycle and activation of repair systems [5-8]. In case of extended DNA damage or insufficient repair mechanisms, the cells will die by apoptosis or other forms according to the cell type, their energy level and the severity of the lesion [4]. These factors may also influence the delay from the lethal hit to the cell demise.

For the monitoring of the therapeutic efficacy, the quantification of cell death can be applied directly by microscopy or by measurement of cell death products both in tumor tissue and in the circulating blood. The most convenient und less invasive method is the detection of the final products in serum or plasma. If performed during the therapy, it may provide an actual image of the cell death kinetics.

Typical products of cell death are nucleosomes - complexes which are formed from a core particle of several histone components and DNA on the outside $[9,10]$. During cell death, endonucleases preferentially bind to the easy accessible linking sites between the nucleosomes and cut the chromatin into multiple mono- and oligonucleosomes $[11,12]$. In cases of enhanced cell death, e.g. during radiotherapy, they are also released into the circulation and can be detected in elevated amounts in serum or plasma.

Former studies on serial measurements of nucleosomes in the serum of cancer patients during radiotherapy revealed a steep increase in the nucleosomal number 1-3 days after the start of treatment followed by a decline that showed interindividual differences in the time delay and the rate of decrease. Patients with a rapid and complete decline in the nucleosome number were found to have an efficient reduction in the tumor volume; those with constantly high values or a delayed and incomplete decrease were correlated with a poor response to therapy and progressive disease [13].

As cells of various origin are degraded in (or also outside) the radiation field, it was highly interesting to explore to which extent dying normal and tumor cells contribute to the quantity of circulating nucleosomes and whether the increase in nucleosomes during radiotherapy reflects the extent of tumor cell apoptosis.

Addressing these questions, we investigated in vitro the sensitivity of both cell types to radiation by exposing normal epithelial cells and squamous lung cancer cells to different doses of ionizing radiation. After this single hit, the number of nucleosomes in the supernatant of the cell cultures was quantified daily for 5 days in order to gain insight in the dose- and time-dependent cell death processes after irradiation.

\section{Materials and Methods}

\section{Culture Techniques}

BEAS-2B is an immortalised human bronchial epithelium cell line and was kindly provided by Prof. D.A. Gillissen, Department of Pneumology, University of Bonn, Germany. The EPLC 32M1 is an adherent-growing non-small cell lung cancer line that was derived from a human squamous-cell carcinoma [14] and was kindly provided by Dr. G. Jaques, University of Marburg, Germany.

Both cell lines were grown until they were confluent in multi-well dishes (Falcon, Lincoln Park, N.J., USA) using RPMI 1640 culture medium (Seromed, Heidelberg, Germany), supplemented with 10\% new born calf serum, $2 \mathrm{~m} M L$-glutamine and antibiotics (all Lifetechnologies, Eggenstein, Germany) in a humidified $5 \% \mathrm{CO}_{2}$ atmosphere.

\section{Irradiation of BEAS-2B and EPLC}

Confluent BEAS-2B and EPLC were irradiated on a single occasion with 0,10 or $30 \mathrm{~Gy}$ in the Department of Radiotherapy, LudwigMaximilians-University Munich, using the linear accelerator Sli 15 (Elekta, Hamburg, Germany) at a high dose of $4 \mathrm{~Gy} / \mathrm{min}$. The shamirradiated group $(0 \mathrm{~Gy})$ was subjected to the same procedure without irradiation. A total of 18 BEAS-2B cultures and 18 EPLC were used in the experiments.

\section{Measurement of Nucleosomes}

Immediately before and at 24-hour intervals (up to $96 \mathrm{~h}$ after irradiation), the supernatants of the BEAS-2B and EPLC cultures were changed, aliquoted, frozen at $-20^{\circ} \mathrm{C}$ and transferred to the Institute of Clinical Chemistry of the Ludwig-Maximilians-University. The concentration of the nucleosomes was measured using a modified

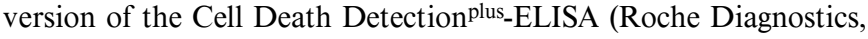
Germany) [15].

The Cell Death Detection plus-ELISA is based on a quantitative sandwich enzyme immunoassay principle: monoclonal mouse anti- 
bodies directed against DNA (ss- and ds-DNA) and histones (H1, $\mathrm{H} 2 \mathrm{~A}, \mathrm{H} 2 \mathrm{~B}, \mathrm{H} 3$ and $\mathrm{H} 4$ ) detect specifically mono- and oligonucleosomes.

The supernatant was placed in a streptavidin-coated microtiter plate and incubated with a mixture of anti-histone-biotin, anti-DNAperoxidase and incubation buffer (1\% BSA, 0.5\% Tween, $1 \mathrm{mM}$ EDTA in PBS) for $2 \mathrm{~h}$. The antibodies bound to the histone and DNA component of the nucleosomes, respectively, and fixed the immunocomplexes to the microtiter plate by streptavidin-biotin interaction. After the incubation period, unbound antibodies were removed by a washing step. The retained peroxidase-linked complexes were incubated with 2,2'-azino-di(3-ethylbenzthiazolin-sulfonate). The substrate reacted with the peroxidase resulting in color development proportional to the amount of nucleosomes captured in the antibody-sandwich. Quantification of the nucleosomes was performed by photometrical determination of the absorbance at $405 \mathrm{~nm}$ against substrate solution as blank (reference wavelength $492 \mathrm{~nm}$ ).

\section{Measurement of Cell Number}

BEAS-2B cells were grown in a second culture, and cells were harvested daily at the time the supernatant was changed in the first culture. Viable cells were identified using a trypan blue staining and counted in a Neubauer counting chamber.

\section{Statistics}

The values in the text are expressed as medians and ranges. The increases and decreases in the time-dependent kinetic investigations are calculated between the several medians in percent changes. The Wilcoxon test was used (1) to compare the experimental groups (control, and 10 and $30 \mathrm{~Gy}$ ), (2) to compare the values during irradiation with the pre-irradiation value and (3) to compare the values of two specific groups (BEAS-2B and EPLC) which were treated with the same doses (10 and $30 \mathrm{~Gy}$ ). A p value $<0.05$ was considered statistically significant.

The values in the figures are presented as medians, and additionally as 25 th and 75 th percentiles (bars).

\section{Results}

During the observation period, the cell number of nonirradiated BEAS-2B increased slightly (median initially: $1.44 \times 10^{6} \mathrm{cells} / \mathrm{culture}$, range $1.07-1.85 \times 10^{6} \mathrm{cells} / \mathrm{cul}-$ ture; after $120 \mathrm{~h}: 4.81 \pm 3.18 \times 10^{6}$ cells/culture, range $1.50-9.54 \times 10^{6}$ cells/culture; increase of $\left.235 \%\right)$. In BEAS-2B irradiated with $10 \mathrm{~Gy}$, the cell number decreased rapidly, reaching very low levels already after $72 \mathrm{~h}$ $\left(0.27 \times 10^{6}\right.$ cells/culture, range $0.05-0.39 \times 10^{6}$ cells $/$ culture) corresponding with a decrease of $81 \%(p=0.031)$. In BEAS-2B irradiated with $30 \mathrm{~Gy}$, the reduction in the cell number started already after $24 \mathrm{~h}$, and after $72 \mathrm{~h}$ it reached $0.19 \times 10^{6}$ cells/culture (range $0.09-0.31 \times 10^{6}$ cells/culture) corresponding to a decrease of $87 \%(\mathrm{p}=$ 0.031 ). The decline in the values continued during the following days. The lowest numbers were obtained after 120 h (10 Gy: $0.03 \times 10^{6}$ cells/culture, range $0.02-0.08 \times$

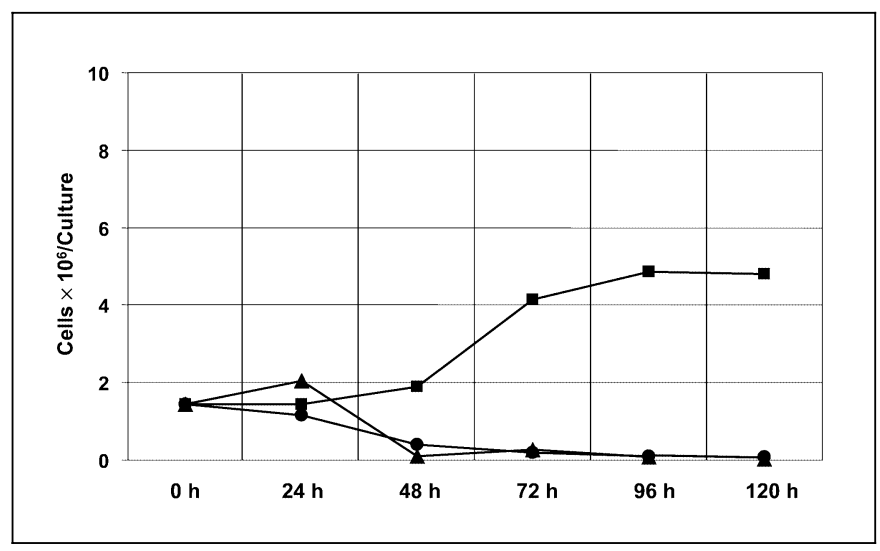

Fig. 1. Kinetics of the cell number of normal BEAS-2B (medians) without irradiation ( $\boldsymbol{\square})$ (control group) and after irradiation with $10 \mathrm{~Gy}(\mathbf{\Lambda})$ and $30 \mathrm{~Gy}(\mathbf{O})$. Cells were harvested before irradiation $(0 \mathrm{~h})$, and 24, 48, 72, 96 and $120 \mathrm{~h}$ after single-dose irradiation.

$10^{6}$ cells/culture, decrease of $98 \% ; 30$ Gy: $0.08 \times 10^{6}$ cells/culture, range $0.02-0.14 \times 10^{6}$ cells/culture, decrease of $95 \%$ ), being highly significant ( $10 \mathrm{~Gy}: \mathrm{p}=0.005$, $30 \mathrm{~Gy}: \mathrm{p}=0.005)$ compared with the non-irradiated control group $\left(4.81 \times 10^{6}\right.$ cells/culture, range $1.50-9.54 \times$ $10^{6}$ cells/culture) (fig. 1$)$.

Also, nucleosomes increased constantly and slightly in the supernatant of non-irradiated BEAS-2B (initially: $0.18 \times 10^{3}$ arbitrary units (AU), range $0.07-0.47 \times 10^{3}$ $\mathrm{AU}$; after $120 \mathrm{~h}: 0.63 \times 10^{3} \mathrm{AU}$, range $0.44-2.17 \times 10^{3}$ $\mathrm{AU}$; increase of $246 \%$ ). However, after irradiation with $10 \mathrm{~Gy}, \mathrm{BEAS}-2 \mathrm{~B}$ increased rapidly reaching a maximum at $72 \mathrm{~h}$ (before irradiation: $0.24 \times 10^{3} \mathrm{AU}$, range 0.13 $4.09 \times 10^{3} \mathrm{AU}$; after $72 \mathrm{~h}: 1.94 \times 10^{3} \mathrm{AU}$, range $0.11-$ $5.70 \times 10^{3} \mathrm{AU}$; increase of $\left.693 \% ; \mathrm{p}=0.219\right)$ and after $120 \mathrm{~h}$ almost dropped to values before treatment $(0.30 \times$ $10^{3} \mathrm{AU}$, range $0.07-0.55 \times 10^{3} \mathrm{AU}$; decrease of $537 \%$ ). At $30 \mathrm{~Gy}$, the release was even stronger, with an earlier peak already after $48 \mathrm{~h}$ (before irradiation: $0.29 \times 10^{3}$ $\mathrm{AU}$, range $0.14-2.68 \times 10^{3} \mathrm{AU}$; after $48 \mathrm{~h}: 11.09 \times 10^{3}$ $\mathrm{AU}$, range $6.89-18.28 \times 10^{3} \mathrm{AU}$; increase of $3,763 \% ; \mathrm{p}=$ 0.031 ) followed by a decline to low levels after $120 \mathrm{~h}$ $\left(0.82 \times 10^{3} \mathrm{AU}\right.$, range $0.24-1.36 \times 10^{3} \mathrm{AU}$; decrease of $1,245 \%)$. For all time points investigated immediately after irradiation (24-96 h), the differences between the sham group and the group irradiated with $30 \mathrm{~Gy}$ were highly significant $(\mathrm{p}<0.05)$ (fig. 2).

In non-irradiated EPLC, the levels of nucleosomes increased constantly (initially: $2.48 \times 10^{3} \mathrm{AU}$, range $1.58-4.83 \times 10^{3} \mathrm{AU}$; after $96 \mathrm{~h}: 5.14 \times 10^{3} \mathrm{AU}$, range 2.80-11.82 $\times 10^{3} \mathrm{AU}$; increase of 107\%). In EPLC irra- 

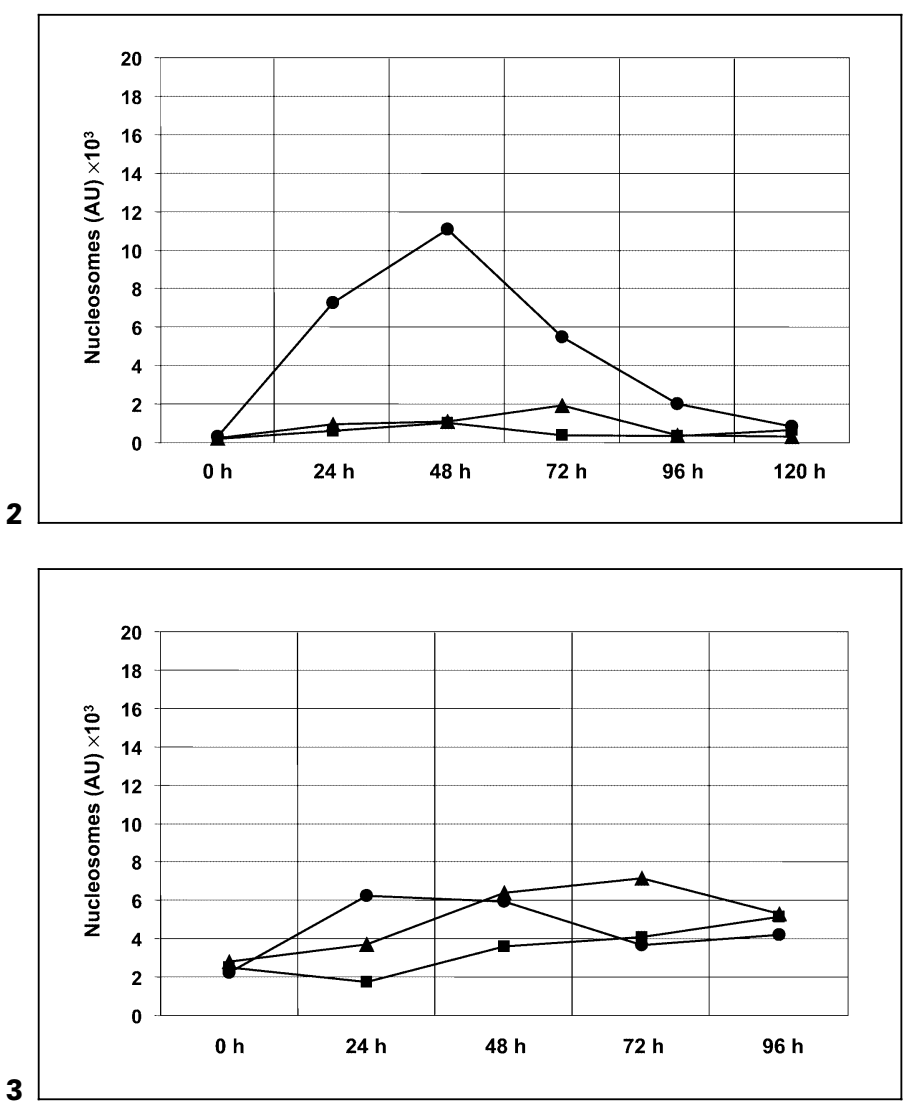

Fig. 2. Release of nucleosomes after irradiation of normal BEAS-2B (medians) without irradiation ( $\mathbf{\square})$ (control group) and after irradiation with $10 \mathrm{~Gy}(\mathbf{\Delta})$ and $30 \mathrm{~Gy}(\mathbf{O})$. Nucleosomes were measured in the culture supernatant before irradiation $(0 \mathrm{~h})$, and 24, 48, 72, 96 and $120 \mathrm{~h}$ after single-dose irradiation.

Fig. 3. Release of nucleosomes after irradiation of EPLC (medians) without irradiation (ם) (control group) and after irradiation with $10 \mathrm{~Gy}(\boldsymbol{\Delta})$ and $30 \mathrm{~Gy}(\mathbf{O})$. Nucleosomes were measured in the culture supernatant before irradiation $(0 \mathrm{~h})$, and $24,48,72$ and $96 \mathrm{~h}$ after single-dose irradiation.

diated with $10 \mathrm{~Gy}$, we observed a considerably higher release of nucleosomes with the maximum again at $72 \mathrm{~h}$ (before irradiation: $2.79 \times 10^{3} \mathrm{AU}$, range 2.42-3.80 $\times$ $10^{3} \mathrm{AU}$; after $72 \mathrm{~h}: 7.16 \times 10^{3} \mathrm{AU}$, range $4.30-16.20 \times$ $10^{3} \mathrm{AU}$; increase of $157 \% ; \mathrm{p}=0.031$ ). After $96 \mathrm{~h}$, the values were comparable with the non-irradiated group (5.31 $\times 10^{3} \mathrm{AU}$, range $\left.4.71-13.76 \times 10^{3} \mathrm{AU}\right)$. In EPLC treated with $30 \mathrm{~Gy}$, the maximum $\left(6.22 \times 10^{3} \mathrm{AU}\right.$, range 5.13 $9.71 \times 10^{3} \mathrm{AU}$; increase of $\left.180 \% ; \mathrm{p}=0.031\right)$ was observed already after $24 \mathrm{~h}$ followed by a slow decline (after $96 \mathrm{~h}: 4.19 \times 10^{3} \mathrm{AU}$, range 3.29-9.27 × $\left.10^{3} \mathrm{AU}\right)$ (fig. 3).
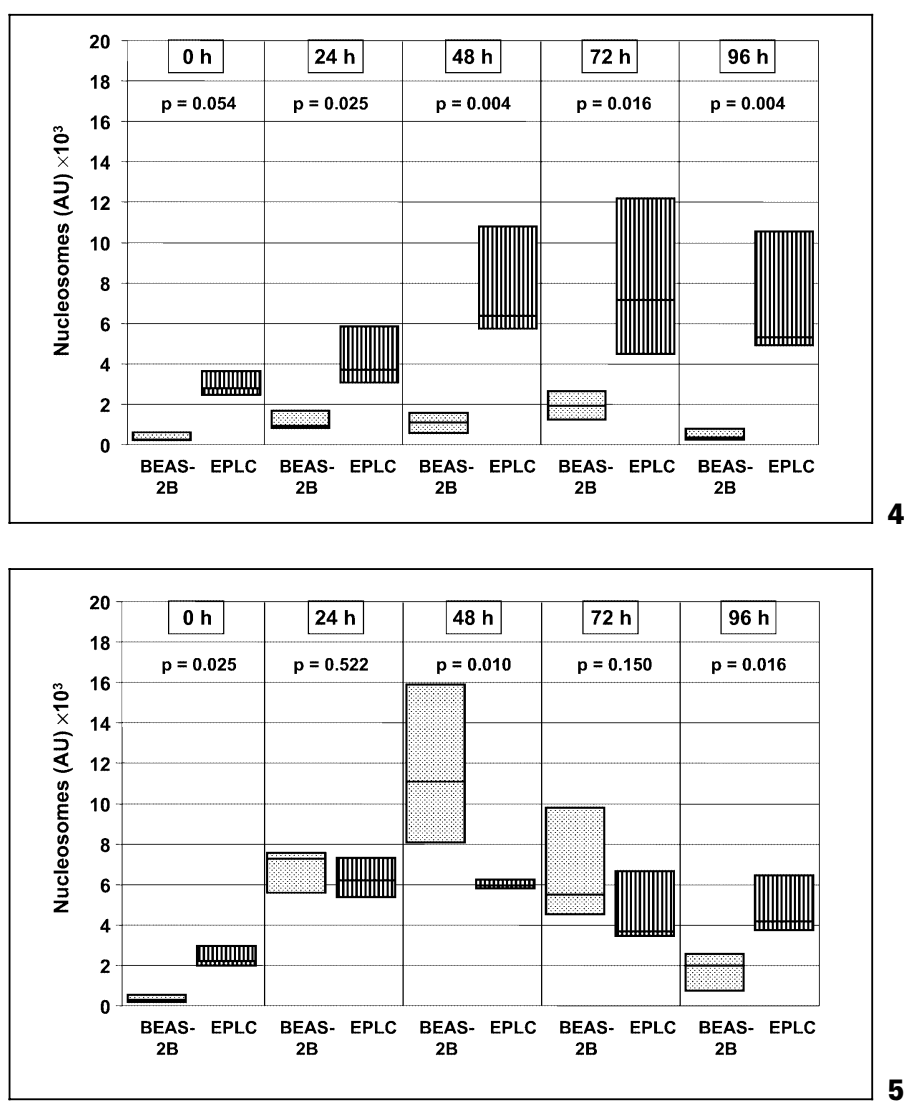

Fig. 4. Release of nucleosomes after irradiation of BEAS-2B (阁) and EPLC (四) with $10 \mathrm{~Gy}$. Nucleosomes were measured in the culture supernatant before irradiation $(0 \mathrm{~h})$, and 24, 48, 72 and $96 \mathrm{~h}$ after single-dose irradiation. Medians, and 25th and 75th percentiles are shown. $p$ values indicating differences between the groups were calculated by Wilcoxon test.

Fig. 5. Release of nucleosomes after irradiation of BEAS-2B (觧) and EPLC (四) with $30 \mathrm{~Gy}$. Nucleosomes were measured in the culture supernatant before irradiation $(0 \mathrm{~h})$, and 24, 48, 72 and $96 \mathrm{~h}$ after single-dose irradiation. Medians, and 25 th and 75 th percentiles are shown. $\mathrm{p}$ values indicating differences between the groups were calculated by Wilcoxon test.

Comparing BEAS-2B and EPLC which were irradiated with $10 \mathrm{~Gy}$, EPLC started before therapy from a higher level (EPLC: $2.79 \times 10^{3} \mathrm{AU}$, range 2.42-3.80 × $10^{3} \mathrm{AU}$; BEAS-2B: $0.24 \times 10^{3} \mathrm{AU}$, range 0.13-4.09 $\times 10^{3} \mathrm{AU}$; $\mathrm{p}=0.054)$ and exhibited a stronger increase. After $72 \mathrm{~h}$, EPLC levels $\left(7.16 \times 10^{3} \mathrm{AU}\right.$, range 4.30-16.20 $\times 10^{3}$ $\mathrm{AU})$ were more than 3.5 times higher than BEAS-2B levels $\left(1.94 \times 10^{3} \mathrm{AU}\right.$, range $0.11-5.70 \times 10^{3} \mathrm{AU} ; \mathrm{p}=$ 0.016). The subsequent decline after $96 \mathrm{~h}$ was less pronounced in EPLC than in BEAS-2B (EPLC: $5.31 \times 10^{3}$ $\mathrm{AU}$, range 4.71-13.76 $\times 10^{3} \mathrm{AU}$; BEAS-2B: $0.37 \times 10^{3}$ $\mathrm{AU}$, range $\left.0.22-1.04 \times 10^{3} \mathrm{AU} ; \mathrm{p}=0.004\right)$ (fig. 4). 
After irradiation with $30 \mathrm{~Gy}$, both cell lines showed a rapid and strong increase. The release of nucleosomes of BEAS-2B (with its maximum after $48 \mathrm{~h}$ ) was significantly higher than that of EPLC (BEAS-2B: $11.09 \times 10^{3} \mathrm{AU}$, range 6.89-18.28 $\times 10^{3} \mathrm{AU}$; EPLC: $5.95 \times 10^{3} \mathrm{AU}$, range 4.31-8.35 $\times 10^{3} \mathrm{AU} ; \mathrm{p}=0.010$ ). However, nucleosome values from EPLC reached their peak already after $24 \mathrm{~h}$. Once again, the following decrease in the values was more pronounced for BEAS-2B than for EPLC after $96 \mathrm{~h}$ (BEA-2B: $1.99 \times 10^{3} \mathrm{AU}$, range 0.72-3.93 $\times 10^{3} \mathrm{AU}$; EPLC: $4.19 \times 10^{3} \mathrm{AU}$, range $3.29-9.27 \times 10^{3} \mathrm{AU} ; \mathrm{p}=$ $0.016)$ (fig. 5).

\section{Discussion}

The induction of cell death in malignant cells is the basis of the antitumor effect of ionizing radiation. Besides cancer cells, normal epithelial cells, lymphocytes and stem cells are also damaged and killed leading potentially to complications during therapy [1]. In order to reduce tumor size and to limit side effects, several protocols have been developed optimizing dosage and frequency of radiotherapy. The monitoring of the response to radiotherapy is mainly performed by imaging techniques. However, for early information and for serial measurements, serum biomarkers indicating the extent of cell death would be valuable for predicting response to therapy and treatment monitoring. In a recent study in 16 patients with various cancers, we described that the kinetics of nucleosomes, during the initial phase of radiotherapy, correlated with the clinical outcome that was estimated by imaging techniques later on [13]. As these nucleosomes could derive from various origins, we investigated here in vitro the dose- and time-dependent release of nucleosomes in normal and malignant bronchoepithelial cells of the lung in order to estimate the contribution of both cell types to the nucleosome values obtained.

The effective damage of the cells by irradiation was shown by the rapid and complete reduction in the cell number in BEAS-2B irradiated with 10 and $30 \mathrm{~Gy}$. In contrast, non-irradiated BEAS-2B exhibited a constantly increasing cell number. In EPLC the cell number was quantified only $96 \mathrm{~h}$ after irradiation, which was comparable to the results of BEAS-2B (data not shown).

It is likely that the increasing amount of untreated cells is not only due to proliferation but also to cell death processes. Strong evidence for this hypothesis is given by the values of nucleosomes which reflect the extent of cell death. They increased in parallel and in a comparable magnitude with the cell number in BEAS-2B. A similar phenomenon was observed in EPLC, but nucleosome values started initially from a higher level. This indicates a higher spontaneous turnover in malignant cells and correlates with in vivo findings of elevated spontaneous nucleosome values in the serum of patients with malignant diseases $[13,16]$. Even if the cell number is decreasing rapidly in irradiated cell lines, a mixture of degradation and proliferation might still occur only with a stronger prevalence of cell death.

Nucleosomes increased in both BEAS-2B and EPLC during irradiation in a dose- and time-dependent manner. As nucleosomes are intracellular components released during cell death, their quantity reflects the number of cells dying spontaneously or after lethal damage by irradiation. Generally, the cell killing effect of radiation was observed in both BEAS-2B and EPLC as a considerable increase in nucleosomes after treatment with 10 and with 30 Gy.

A dosage of 30 Gy resulted in an early (after 24 to $48 \mathrm{~h}$ ) and high maximum of nucleosomes. Because of the strong damage, many cells are probably killed immediately after exposure to irradiation and are not able to activate any cellular rescuing mechanisms. At $10 \mathrm{~Gy}$, the maximum was observed later and less pronounced compared with the higher dosage in BEAS-2B. In this case, cells might still have the possibility to arrest their cell cycle and enable the repair of DNA damages. Only if they cannot be compensated appropriately, these cells will be determined to undergo cell death later on [17]. This hypothesis is supported by the well-known upregulation of p53 after radiation-induced DNA damages. p53 is involved in cell cycle arrest as well as in the regulation of apoptosis. In case of extended damage, or dysfunctional or insufficient repair systems, p53 induces apoptotic cell death by activation of $\mathrm{BAX}, \mathrm{BAD}$, and the mitochondrial release of cytochrome C [5-8]. Since tumor cells frequently exhibit a high spontaneous instability of DNA and their repair mechanisms are often dysfunctional due to specific mutations, they are likely to present a damaged DNA which cannot be eliminated adequately $[17,18]$. This explains the high spontaneous rate of cell death in malignant cells as well as their high sensitivity to radio- and chemotherapy. Consistently, in EPLC we found a strong effect of irradiation already at $10 \mathrm{~Gy}$, which could not be enhanced by $30 \mathrm{~Gy}$.

Comparing BEAS-2B and EPLC, the maximum obtained after irradiation with 10 Gy was significantly higher in EPLC, underlining the high sensitivity of tumor cells to irradiation. After irradiation with $30 \mathrm{~Gy}$, both cell lines demonstrated a rapid and strong increase, with BEAS-2B 
reaching higher maximum levels. Subsequently, the values dropped more significantly in BEAS-2B than in EPLC probably caused by the higher rate of spontaneous proliferation and cell death in EPLC.

The massive induction of apoptosis in HeLa Hep2 cells has been described earlier in an immunohistochemical study by Mirzaie-Joniani et al. [3]. Up to $60 \%$ of the cells irradiated with 5 and 15 Gy displayed apoptotic characteristics detected by TUNEL and M30 CytoDEATH technology. Doses below 2 Gy did not have any effect. The highest induction rate was seen after treatment with 5 Gy. Higher doses did not significantly raise apoptotic rates. The values increased already after $24 \mathrm{~h}$ and reached the peak after $168 \mathrm{~h}$ [3]. Unfortunately, the values between $72 \mathrm{~h}$ and $168 \mathrm{~h}$ after irradiation were not investigated.

In accordance with this study, we confirm that techniques measuring cell death characteristics are useful tools for the estimation of in vitro radiosensitivity in cell lines. Further, we demonstrated that nucleosomes reflect the extent of cell death induced by irradiation. Our results indicate that normal bronchoepithelial and malignant lung cancer cells contribute to the release of nucleosomes during irradiation in a dose- and time-dependent manner. At low doses, cancer cells had a clearly higher effect on the release of nucleosomes.

In vivo, the situation during radiotherapy is more complex: Normal and malignant cells integrated in tissue might react differently to irradiation possibly in relation to the linkage with adjacent cells. Therefore, further studies in whole organ cultures consisting of tumor cells, fibroblasts and normal bronchoepithelial cells might reveal new insights in tissue radiosensitivity $[19,20]$.

\section{Acknowledgments}

This study was supported by the Wilhelm Sander Foundation grant 2000.077.1 to A.B. and R.M.H. The nucleosome assays were provided by P. Bialk and B. Eckert, Roche Diagnostics, Germany.

\section{References}

1 Hendry JH, West CM: Apoptosis and mitotic cell death: Their relative contributions to normal-tissue and tumour radiation response. Int $\mathrm{J}$ Radiat Biol 1997;71:709-719.

2 Mirkovic N, Meyn RE, Hunter NR, Milas L: Radiation-induced apoptosis in a murine lymphoma in vivo. Radiother Oncol 1994;33:1116.

3 Mirzaie-Joniani H, Eriksson D, Sheikholvaezin A, Johansson A, Löfroth PO, Johansson L, Stigbrand T: Apoptosis induced by low-dose and low-dose-rate radiation. Cancer 2002;94: 1210-1214

4 Leist M, Nicotera P: The shape of cell death. Biochem Biophys Res Commun 1997;236:19.

5 Szumiel I: Monitoring and signaling of radiation-induced damage in mammalian cells. Radiat Res 1998;150:92-101.

6 Albrechtsen N, Dornreiter I, Grosse F, Kim E, Wiesmüller L, Deppert W: Maintenance of genomic integrity by p53: Complementary roles for activated and non-activated p53. Oncogene 1999; 18:7706-7717.

7 Sionov RV, Haupt Y: The cellular response to p53:The decision between life and death. Oncogene 1999; 18:6145-6157.

8 Hengartner MO: The biochemistry of apoptosis. Nature 2000;407:770-776.
9 Kornberg R, Lorch Y: Twenty-five years of the nucleosome, fundamental particle of the eukaryote chromosome. Cell 1999;98:285-294.

10 Luger K, Mäder AW, Richmond RK, Sargent DF, Richmond TJ: Crystal structure of the nucleosome core particle at 2.8. A resolution. Nature 1997;389:251-260.

11 Kerr JF, Winterford CM, Harmon BV: Apoptosis. Its significance in cancer and cancer therapy. Cancer 1994;73:2013-2026.

12 Wyllie AH, Arends MJ, Morris RG, Walker SW, Evan G: The apoptosis endonuclease and its regulation. Semin Immunol 1992;4:389397.

13 Holdenrieder S, Stieber P, Bodenmüller H, Busch M, Fertig G, Fürst H, Schalhorn A, Schmeller N, Untch M, Seidel D: Nucleosomes in serum of patients with benign and malignant diseases. Int J Cancer 2001;95:114-120.

14 Bepler G, Koehler A, Kiefer P, Havemann K, Beisenherz K, Jaques G, Gropp C, Haeder M: Characterization of the state of differentiation of six newly established human non-small-cell lung cancer cell lines. Differentiation 1988;37: 158-171.
15 Holdenrieder S, Stieber P, Bodenmüller $\mathrm{H}$ Fertig G, Fürst H, Schmeller N, Untch M, Seidel D: Nucleosomes in serum as a marker for cell death. Clin Chem Lab Med 2001;39:596605.

16 Kuroi K, Tanaka C, Toi M: Plasma nucleosome levels in node-negative breast cancer patients. Breast Cancer 1999;6:361-364.

17 Schär P: Spontaneous, DNA damage, genome instability, and cancer - When DNA replication escapes control. Cell 2001;104:329-332.

18 Hendry JH: Genomic instability: Potentia contributions to tumour and normal tissue response, and second tumours, after radiotherapy. Radiother Oncol 2001;59:117-126.

19 Al-Batran SE, Astner ST, Supthut M, Gamarra F, Brueckner K, Welsch U, Knuechel R, Huber RM: Three-dimensional in vitro cocultivation of lung carcinoma cells with human bronchial organ culture as a model for bronchial carcinoma. Am J Respir Cell Mol Biol 1999;21:200208.

20 Bergner A, Stief J, Holdenrieder S, Stieber P, Haimerl W, Passlick B, Waldschmidt A, Kummermehr J, Gamarra F, Huber RM: Effects of single-dose irradiation on bronchial epithelium: A comparison of BEAS 2B cell monolayers, human organ cultures and Goettinger minipigs. Radiat Res 2003;160:647-654. 